\title{
GAMBARAN SIKAP IBU POSTPARTUM PADA KEPERCAYAAN BUDAYA MELAYU
}

\author{
Mirawati $^{1}$, Dian Roza Adila ${ }^{2}$, Sekani Niriyah ${ }^{3}$ \\ ${ }^{1,2,3}$ Program Studi Keperawatan STIKes Hangtuah Pekanbaru \\ STIKes Hang Tuah Pekanbaru Jalan Mustafa Sari No. 5 \\ Tangkerang Selatan Pekanbaru Riau Kode Pos 28000 Indonesia \\ Email: mira.asus5@gmail.com
}

\begin{abstract}
Abstrak
Periode postpartum dimulai sejak bayi dilahirkan dan kembalinya sistem organ reproduksi kekeadaan normal seperti semula, atau disebut juga trimester keempat kehamilan. Kebanyakan perilaku ibu pada masa postpartum dipengaruhi oleh faktor budaya yang memiliki berbagai kepercayaan dan praktik tradisional. Praktik kesehatan tradisional ini sering diterapkan wanita dan keluarga yang masa periode postpartum. Tujuan penelitian ini adalah untuk mengetahui gambaran sikap ibu postpartum dengan kepercayaan budaya Melayu. Penelitian ini adalah jenis penelitian kuantitatif dengan menggunakan desain pendekatan retrospektif. Jumlah sampel penelitian 43 orang yang diambil menggunakan teknik non random sampling. Data dianalisis secara univariat menggunakan distribusi frekuensi. Hasil penelitian diperoleh sebanyak $31(72,1 \%)$ orang responden memiliki sikap negatif pada budaya Melayu. Selama postpartum sikap ibu sudah baik sesuai dengan kesehatan, ibu sudah menjauhi kepercayaan budaya melayu selama masa postpartum.
\end{abstract}

Kata Kunci : Budaya Melayu, Postpartum, Sikap

\begin{abstract}
The postpartum period starts from the time the baby is born and the reproductive organ system returns to its normal state as before, or also called the fourth trimester of pregnancy. Most maternal behavior in the postpartum period is influenced by cultural factors that have various traditional beliefs and practices. This traditional health practice is often applied by women and families in the postpartum period. The purpose of this study was to determine the description of postpartum mothers' attitudes with Malay cultural beliefs. This research is a type of quantitative research using a retrospective approach design. The number of research samples 43 people taken using non random sampling techniques. Data were analyzed univariately using a frequency distribution. The results obtained by 31 (72.1\%) of respondents have a negative attitude to Malay culture. During postpartum the mother's attitude is good in accordance with health, the mother has shunned the cultural beliefs of Malay during the postpartum period.
\end{abstract}

Keywords: Malay Culture, Postpartum, Attitude

\section{PENDAHULUAN}

Periode postpartum (masa nifas) dimulai sejak bayi dilahirkan dan kembalinya sistem organ reproduksi ke keadaan normal seperti semula, atau disebut juga trimester keempat kehamilan.
Periode post partum dikatakan secara tradisional berlangsung 6 minggu dan lamanya bervariasi pada setiap wanita. Perubahan fisiologis yang terjadi selama masa nifas mulai dari kembalinya uterus kebentuk semula, serviks akan memendek 
Mirawati $^{1}$, Dian Roza Adila ${ }^{2}$, Sekani Niriyah ${ }^{3}$, Gambaran Sikap Ibu Postpartum pada Kepercayaan Budaya Melayu

dan mengeras selama 12-18 jam kedepan, vagina perlahan akan mengecil kembali, abdomen kembali semula selama 6 minggu, fungsi ginjal menurun dan kembali normal dalam 1 bulan, dan penurunan kadar hormon pada payudara kembalinya hormon ditentukan apakah ibu menyusui atau tidak (Lowdermilk, Perry \& Cashion 2013).

Masa setelah persalinan atau periode post partum sangat penting karena merupakan fase kritis dalam kehidupan ibu dan bayi yang baru lahir. Periode ini memiliki resiko kesehatan yang besar bagi ibu dan bayi baru lahir. Perawatan pada periode setelah post partum sangat penting, tidak hanya untuk bertahan hidup tetapi juga untuk masa depan ibu dan bayi baru lahir. Perubahan yang terjadi pada periode ini akan menentukan kesejahteraan ibu dan bayi pada kesehatan masa depan (WHO, 2010).

Periode post partum ini penting diperhatikan oleh tenaga kesehatan karena pada periode ini rencana perawatan meliputi pencegahan infeksi pada perineum agar mencegah infeksi diarea sistem perkemihan. Setelah melahirkan ibu dianjurkan untuk beristirahat dan tidur karena harus memenuhi kebutuhan bayi dimalam hari sehingga sering terbangun. Ibu post partum juga dianjurkan untuk beraktivitas atau latihan kegel sesering mungkin untuk menggerakkan otot vagina serta menguatkan otot-otot punggung. Dalam proses pemulihan masa post partum, ibu dianjurkan untuk mengkonsumsi asupan makanan yang mengandung tinggi protein, kalori dan cairan untuk memenuhi kebutuhan gizi ibu (Lowdermilk, Perry \& Cashion 2013).

Selain dalam segi kesehatan perawatan periode post partum juga dilihat dari konteks sosial budaya atau keyakinan yang dipercayai oleh ibu selama masa post partum. Kepercayaan dan keyakinan budaya terhadap perawatan ibu post partum masih banyak dijumpai dilingkungan masyarakat. Mereka meyakini budaya perawatan ibu setelah melahirkan dapat memberikan dampak yang positif dan menguntungkan bagi mereka. Hal ini terbukti dari penelitian yang dilakukan oleh Rahayu, Mudatsir, dan Hasballah (2017) pada 10 orang ibu post partum di Kecamatan Tanah Aceh Jambo Aye Kabupaten Aceh Utara menjelaskan pengalaman ibu setelah melahirkan didapatkan kepercayaan dan keyakinan meliputi tradisi Badapu yaitu memanaskan tubuh ibu pada pagi dan sore hari dengan nyala api tungku. Melakukan tradisi Madeung dan Toet Batee merupakan perawatan budaya ibu nifas yang meyakini mempercepat pemulihan masa persalinan, membersihkan darah kotor, 
mengembalikan otot dan merampingkan tubuh.

Kebanyakan perilaku ibu pada masa post partum dipengaruhi oleh faktor budaya yang memiliki berbagai kepercayaan dan praktik tradisional. Praktik kesehatan tradisional ini sering diterapkan wanita dan keluarga yang masa periode post partum. Perilaku keluarga dalam mencari pelayanan kesehatan dan hubungan dengan petugas kesehatan dipengaruhi oleh kepercayaan serta nilai-nilai kesehatan yang terkait budaya. Pada akhirnya semua faktor ini memiliki kekuatan untuk mempengaruhi kesehatan ibu dan anak. Kepercayaan tersebut meliputi ibu tidak boleh bergerak, tidak mandi dan harus ditempat tidur untuk mencegah udara dingin masuk ditubuhnya (Lowdermilk, Perry \& Cashion 2013).

Berdasarkan penelitian Sembiring (2011) mengatakan masyarakat suku Melayu masih banyak melestarikan budaya-budaya para pendahulunya. Berbagai fenomena perawatan masa nifas yang dilakukan oleh ibu-ibu suku Melayu mencakup pantangan makan seperti dilarang mengkonsumsi sayuran (kangkung dan genjer) karena dianggap menyebabkan vagina menjadi licin. Sebaliknya dalam ilmu kesehatan ibu nifas dianjurkan lebih banyak mengkonsumsi sayuran hijau untuk kesehatan ibu dan bayi. Kemudian beberapa pantangan seperti dilarang mengkonsumsi daging dan ikan, hal ini tidak selaras dengan persepsi ilmu kesehatan yang menganjurkan ibu mengkonsumsi daging dan ikan secukupnya untuk kesehatan ibu dan bayinya. Kemudian ada juga perawatan khusus seperti memakai gurita yang sebelumnya diolesi tapel atau krim khusus bersalin pada daerah perut ibu dengan tujuan untuk membuat perut ibu menjadi ketat. Pemakaian gurita tidak baik untuk kesehatan karena dapat mengganggu kenyamanan ibu.

Berdasarkan studi pendahuluan yang dilakukan oleh peneliti pada tanggal 5 Juni 2018 di kelurahan Kampung Bandar peneliti mewawancarai 4 orang ibu bersuku Melayu. Maka didapatkan hasil 3 ibu mengatakan bahwa setelah melahirkan ibu dilarang keluar rumah sebelum 40 hari, dan dilarang memakan telur, daging, santan dan pedas-pedas. Ibu hanya boleh memakan ikan dan sayuran bening seperti jantung pisang, daun katuk dan toge, 1 orang ibu mengatakan bahwa menganggap tidak peduli terhadap larangan atau petuah yang diberikan oleh orangtua karena mereka beranggapan larangan tersebut tidak masuk akal.

Berdasarkan fenomena di atas, peneliti tertarik untuk melakukan penelitian mengenai "Gambaran Sikap Ibu Post Partum pada Kepercayaan Budaya Melayu" 
Mirawati', Dian Roza Adila ${ }^{2}$, Sekani Niriyah ${ }^{3}$, Gambaran Sikap Ibu Postpartum pada Kepercayaan Budaya Melayu

\section{METODE PENELITIAN}

Penelitian ini menggunakan metode penelitian kuantitatif, dengan menggunakan desain pendekatan retrospektif. Populasi dalam penelitian ini adalah ibu yang sudah melahirkan yang berjumlah 43 orang ibu. Jenis teknik sampling menggunakan teknik non random sampling dengan menggunakan metode purposive sampling. Lokasi penelitian dilakukan di Kelurahan Kampung Bandar Pekanbaru, pengambilan data dimulai 23 Februari 2019 di RW 006. Intstrumen penelitian menggunakan lembar kuesioner. Dalam penelitian ini peneliti melakukan uji validitas. Peneliti kemudian melakukan pengolahan data melalui program komputer. Peneliti menganalisis data yang meliputi analisa univariat terkait karakteristik responden, usia, pendidikan terakhir dan variabel sikap ibu postpartum.

\section{HASIL PENELITIAN}

\section{A. Karakteristik responden}

Tabel 1

Distribusi frekuensi karakteristik responden

\begin{tabular}{lcc}
\hline \multicolumn{1}{c}{ Karakteristik } & $\mathrm{f}$ & $\%$ \\
\hline Usia & & \\
Dewasa muda (20-40) & 36 & 83,7 \\
Dewasa tengah (40-60) & 7 & 16,3 \\
Pendidikan & & \\
SD & 3 & 7,0 \\
SMP & 4 & 9,3 \\
SMA & 28 & 65,1 \\
Perguruan Tinggi & 8 & 18,6 \\
\hline
\end{tabular}

Berdasarkan tabel 1 diatas mayoritas responden berusia 20-40 tahun yaitu sebanyak 36 orang $(83,7 \%)$, dan berpendidikan SMA sebanyak 28 orang $(65,1 \%)$.

Tabel 2

Distribusi frekuensi analisis kuesioner

\begin{tabular}{|c|c|c|c|}
\hline No & Pernyataan & $\mathrm{f}$ & $\%$ \\
\hline \multirow[t]{4}{*}{1} & $\begin{array}{l}\text { Saya tidak makan: kangkung, } \\
\text { genjer, daun kacang setelah } \\
\text { melahirkan. }\end{array}$ & & \\
\hline & Sangat setuju & 33 & 76,7 \\
\hline & Setuju & 10 & 23,3 \\
\hline & Total & 43 & 100,0 \\
\hline \multirow[t]{4}{*}{2} & $\begin{array}{l}\text { Saya menjaga untuk tidak } \\
\text { makan daging selama masa } \\
\text { nifas. }\end{array}$ & & \\
\hline & Sangat setuju & 28 & 65,1 \\
\hline & Setuju & 25 & 34,9 \\
\hline & Total & 43 & 100,0 \\
\hline \multirow[t]{5}{*}{3} & $\begin{array}{l}\text { Saya menjaga untuk tidak } \\
\text { makan yang pedas-pedas. }\end{array}$ & & \\
\hline & Sangat tidak setuju & 19 & 44,2 \\
\hline & Tidak setuju & 3 & 7,0 \\
\hline & Setuju & 21 & 48,8 \\
\hline & Total & 43 & 100,0 \\
\hline \multirow[t]{4}{*}{4} & $\begin{array}{l}\text { Saya menjaga untuk tidak } \\
\text { makan nangka dan es. }\end{array}$ & & \\
\hline & Sangat setuju & 39 & 90,7 \\
\hline & Setuju & 4 & 9,3 \\
\hline & Total & 43 & 100,0 \\
\hline \multirow[t]{5}{*}{5} & $\begin{array}{l}\text { Saya tidak boleh keluar } \\
\text { rumah selama } 40 \text { hari setelah } \\
\text { masa nifas. }\end{array}$ & & \\
\hline & Sangat setuju & 36 & 83,7 \\
\hline & Setuju & 6 & 14,0 \\
\hline & Sangat tidak setuju & 1 & 2,3 \\
\hline & Total & 43 & 100,0 \\
\hline \multirow[t]{4}{*}{6} & $\begin{array}{l}\text { Saya dianjurkan untuk tidak } \\
\text { boleh banyak bergerak } \\
\text { selama masa nifas. }\end{array}$ & & \\
\hline & Sangat setuju & 33 & 76,7 \\
\hline & Setuju & 10 & 23,3 \\
\hline & Total & 43 & 100,0 \\
\hline \multirow[t]{4}{*}{7} & $\begin{array}{l}\text { Saya mengoleskan } \\
\text { bengkuang yang sebelumnya } \\
\text { diolesi dengan tapel dengan } \\
\text { daun jarak atau mengkudu } \\
\text { diperut setelah melahirkan. }\end{array}$ & & \\
\hline & Sangat setuju & 38 & 88,4 \\
\hline & Setuju & 5 & 11,6 \\
\hline & Total & 43 & 100,0 \\
\hline \multirow[t]{2}{*}{8} & $\begin{array}{l}\text { Saya membersihkan } \\
\text { kemaluan saya dengan air } \\
\text { sirih yang sudah dimasak } \\
\text { selama masa nifas. }\end{array}$ & & \\
\hline & Sangat setuju & 36 & 83,7 \\
\hline
\end{tabular}




\begin{tabular}{|c|c|c|c|}
\hline No & Pernyataan & $\mathrm{f}$ & $\%$ \\
\hline & Setuju & 7 & 16,3 \\
\hline & Total & 43 & 100,0 \\
\hline \multirow[t]{4}{*}{9} & $\begin{array}{l}\text { Saya meneteskan ke mata air } \\
\text { bilasan keramas yang } \\
\text { terakhir. }\end{array}$ & & \\
\hline & Sangat setuju & 37 & 86,0 \\
\hline & Setuju & 6 & 14,0 \\
\hline & Total & 43 & 100,0 \\
\hline \multirow[t]{4}{*}{10} & $\begin{array}{l}\text { Saya memakai bubuk rempah } \\
\text { yang dicairkan (parem) } \\
\text { dikening. }\end{array}$ & & \\
\hline & Sangat setuju & 37 & 86,0 \\
\hline & Setuju & 6 & 14,0 \\
\hline & Total & 43 & 100,0 \\
\hline \multirow[t]{5}{*}{11} & $\begin{array}{l}\text { Setelah melahirkan saya } \\
\text { mandi seluruh badan } \\
\text { (wiladah). }\end{array}$ & & \\
\hline & Sangat tidak setuju & 22 & 51,2 \\
\hline & Tidak setuju & 1 & 2,3 \\
\hline & Setuju & 20 & 46,5 \\
\hline & Total & 43 & 100,0 \\
\hline \multirow[t]{4}{*}{12} & $\begin{array}{l}\text { Saya meminum ramuan } \\
\text { tradisional kunyit, kencur, } \\
\text { jahe dan rempah ratus setelah } \\
\text { melahirkan. }\end{array}$ & & \\
\hline & Sangat setuju & 40 & 93,0 \\
\hline & Setuju & 3 & 7,0 \\
\hline & Total & 43 & 100,0 \\
\hline \multirow[t]{4}{*}{13} & $\begin{array}{l}\text { Saya dianjurkan untuk minum } \\
\text { banyak selama masa nifas. }\end{array}$ & & \\
\hline & Sangat tidak setuju & 37 & 86,0 \\
\hline & Setuju & 6 & 14,0 \\
\hline & Total & 43 & 100,0 \\
\hline \multirow[t]{4}{*}{14} & $\begin{array}{l}\text { Saya tidak boleh menambah } \\
\text { makan nasi selama masa nifas }\end{array}$ & & \\
\hline & Sangat tidak setuju & 39 & 90,7 \\
\hline & Tidak setuju & 4 & 9,3 \\
\hline & Total & 43 & 100,0 \\
\hline \multirow[t]{4}{*}{15} & $\begin{array}{l}\text { Saya tidak bleh memakan } \\
\text { santan selama masa nifas. }\end{array}$ & & \\
\hline & Sangat setuju & 37 & 86,0 \\
\hline & Setuju & 6 & 14,0 \\
\hline & Total & 43 & 100,0 \\
\hline \multirow[t]{4}{*}{16} & $\begin{array}{l}\text { Saya mengkonsumsi jantung } \\
\text { pisang, daun katuk dan toge } \\
\text { selama asa nifas. }\end{array}$ & & \\
\hline & Sangat tidak setuju & 18 & 41,9 \\
\hline & Setuju & 25 & 58,1 \\
\hline & Total & 43 & 100,0 \\
\hline \multirow[t]{4}{*}{17} & $\begin{array}{l}\text { Saya mengkonsumsi ikan } \\
\text { sungai dan ikan laut selama } \\
\text { masa nifas. }\end{array}$ & & \\
\hline & Sangat tidak setuju & 38 & 88,4 \\
\hline & Setuju & 5 & 11,6 \\
\hline & Total & 43 & 100,0 \\
\hline 18 & $\begin{array}{l}\text { Saya dianjurkan untuk tidak } \\
\text { memakai stagen yang diikat } \\
\text { diperut selama masa nifas. }\end{array}$ & & \\
\hline
\end{tabular}

\begin{tabular}{|c|c|c|c|}
\hline No & Pernyataan & $\mathrm{f}$ & $\%$ \\
\hline \multirow{7}{*}{19} & Sangat tidak setuju & 41 & 95,3 \\
\hline & Tidak setuju & 2 & 4,7 \\
\hline & Total & 43 & 100,0 \\
\hline & $\begin{array}{l}\text { Saya tidak mkan telur selama } \\
\text { masa nifas. }\end{array}$ & & \\
\hline & Sangat setuju & 39 & 90,7 \\
\hline & Setuju & 4 & 9,3 \\
\hline & Total & 43 & 100,0 \\
\hline \multirow[t]{5}{*}{20} & $\begin{array}{l}\text { Saya dilarang untuk duduk } \\
\text { mencangkung. }\end{array}$ & & \\
\hline & Sangat tidak setuju & 31 & 72,1 \\
\hline & Tidak setuju & 1 & 2,3 \\
\hline & Setuju & 11 & 25,6 \\
\hline & Total & 43 & 100,0 \\
\hline \multirow[t]{4}{*}{21} & $\begin{array}{l}\text { Saya tidak mendekatkan } \\
\text { benda tajam seperti gunting } \\
\text { dan peniti selama masa nifas. }\end{array}$ & & \\
\hline & Sangat tidak setuju & 41 & 95,3 \\
\hline & Tidak setuju & 2 & 4,7 \\
\hline & Total & 43 & 100,0 \\
\hline \multirow[t]{4}{*}{22} & $\begin{array}{l}\text { Saya menutup kepala dengan } \\
\text { handuk saat keluar rumah. }\end{array}$ & & \\
\hline & Sangat setuju & 39 & 90,7 \\
\hline & Setuju & 4 & 9,3 \\
\hline & Total & 43 & 100,0 \\
\hline \multirow[t]{4}{*}{23} & $\begin{array}{l}\text { Saya mengikat rambut } \\
\text { dengan kuat menggunakan } \\
\text { paku selama masa nifas. }\end{array}$ & & \\
\hline & Sangat setuju & 38 & 88,4 \\
\hline & Setuju & 5 & 11,6 \\
\hline & Total & 43 & 100,0 \\
\hline \multirow[t]{4}{*}{24} & $\begin{array}{l}\text { Saya tidak percaya larangan } \\
\text { yang dikatakan orang tua } \\
\text { saya selama masa nifas. }\end{array}$ & & \\
\hline & Sangat tidak setuju & 41 & 95,3 \\
\hline & Tidak setuju & 2 & 4,7 \\
\hline & Total & 43 & 100,0 \\
\hline
\end{tabular}

Dari hasil analisis kuesioner tergambar bahwa ibu paling tinggi dianjurkan untuk tidak memakai stagen yang diikat diperut $(95,3 \%)$, tidak mendekatkan benda tajam seperti gunting dan peniti selama masa nifas $(95,3 \%)$, tidak percaya larangan yang dikatakan orang tua selama masa nifas $(95,3 \%)$. 
Mirawati $^{1}$, Dian Roza Adila ${ }^{2}$, Sekani Niriyah ${ }^{3}$, Gambaran Sikap Ibu Postpartum pada Kepercayaan Budaya Melayu

Tabel 3

Distribusi frekuensi analisis sikap ibu postpartum pada kepercayaan budaya Melayu

\begin{tabular}{ccc}
\hline Sikap & F & $\%$ \\
\hline Positif & 12 & 27,9 \\
Negatif & 31 & 72,1 \\
\hline
\end{tabular}

Hasil penelitian menunjukkan sikap ibu postpartum pada kepercayaan budaya Melayu sebanyak sebanyak 31 responden mempunyai sikap negatif.

\section{PEMBAHASAN}

\section{A. Karakteristik Responden}

\section{Usia}

Dari hasil penelitian yang dilakukan di kelurahan kampung bandar Pekanbaru terhadap 43 responden berusia 20-40 tahun yaitu 36 responden $(83,7 \%)$. Penelitian Wulansari dan Yudha (2017) menggambarkan bahwa, salah satu faktor yang mempengaruhi pengetahuan ibu pantang makanan selama masa nifas adalah usia $15-25$ tahun $(63,3 \%)$. Wawan dan Dewi (2010) menjelaskan Semakin cukup tingkat kematangan dan kekuatan seseorang akan lebih matang dalam berfikir dan bekerja .

\section{Pendidikan}

Hasil penelitian menggambarkan bahwa sebagian besar responden berpendidikan SMA yaitu sebanyak 28 orang $(65,1 \%)$. Penelitian ini sejalan dengan penelitian yang dilakukan oleh Wulansari dan Yudha (2017), mengatakan bahwa sebanyak 15 responden $(50 \%)$ ibu nifas primigravida berpendidikan SMA. Wawan dan Dewi (2010) menjelaskan semakin tinggi pendidikan seseorang maka semakin mudah juga menerima informasi.

\section{B. Sikap Ibu Postpartum pada}

\section{Kepercayaan Budaya Melayu}

Dari hasil penelitian didapatkan bahwa mayoritas ibu postpartum memiliki sikap negatif terhadap kepercayaan budaya Melayu (72,1\%). Artinya ibu sudah meninggalkan, menjauhi, dan menghindari budayannya sesuai dengan kesehatan. Hal ini bertolak belakang dengan penelitian Wulansari dan Yudha (2017), sebagian besar ibu selama masa nifas memiliki sikap positif (80\%).

Sikap adalah respons terhadap stimulasi sosial yang telah sesuai dengan kondisi yang terjadi terhadap kesiapan atau antisipatif untuk menyesuaikan diri dalam situasi sosial, atau secara umum dan sederhana dalam menjalani masa postpartum (Azwar, 2012). Menurut Wawan dan Dewi (2010) ada dua sikap yang diungkapkan oleh seseorang terhadap suatu objek. Sikap yang positif cenderung bertindak antara lain mengharapkan, menyenangi, mendekati, dan menyukai sebuah objek. Sikap negatif lebih cenderung untuk menghindari tidak menyukai, menjauhi, bahkan membenci terhadap budaya yang ia miliki. 
Berdasarkan penelitian Sembiring (2011) didapatkannya filosofi kesehatan suku Melayu tentang perawatan ibu pada masa nifas berhubungan dengan keadaan di masa tua. Nilai-nilai yang mendasari praktik budaya terdiri dari pantangan perilaku yaitu tidak boleh keluar selama 40 hari, perilaku khusus yang dilakukan seperti keramas selama seminggu dan memakai pilis di kening. Pantangan makanan seperti pantang makan sayuran kangkung, genjer, ikan, dan daging. Perilaku tersebut tidak sesuai dengan ilmu kesehatan. Berbeda halnya dengan pantangan mengkonsumsi nangka, makanan pedas-pedas dan es sesuai dengan ilmu kesehatan. Ramuan tradisional seperti meminum pati jahe, kencur dan kunyit juga dikonsumsi oleh suku Melayu. Praktek perawatan nifas terdiri dari aktivitas seperti tidak boleh banyak bergerak dan bekerja, pemeliharaan kebersihan diri seperti mandi wiladah dan perawatan khusus seperti memakai air daun sirih untuk membersihkan vagina dan memakai bekung.

Disamping itu, hasil penelitian ini berbeda dengan penelitian Sembiring. Sikap ibu nifas terhadap pantang perilaku sebagian besar sudah meninggalkan pantang seperti tidak memakai bekung (stagen) yang diikat diperut sebanyak (95,3\%). Penelitian Rahayu (2018) mengatakan ibu memakai bekung karena anjuran orang tua terdapat 10 orang ibu nifas (41,67\%), dan mengatakan bekung karena merasa nyaman ada 14 orang ibu $(58,33 \%)$. Hasil dari kegiatan ini terdapat 24 ibu yang menggunakan bekung. Beberapa ibu nifas menyampaikan keluhan karena pemakian bekung yang salah terdapat 9 ibu nifas mengatakan kaki bengkak, $10 \mathrm{ibu}$ mengatakan gatal-gatal dikulit dan dan 3 orang ibu merasa sesak. Dapat disimpulkan cara pemakaian bekung yang salah justru akan merugikan ibu nifas itu sendiri.

Ibu budaya Melayu Riau juga sudah meninggalkan kebiasaan untuk tidak mendekatkan benda tajam seperti gunting dan peneliti sebanyak (95,3\%). Ermiati, Amrullah dan Santoso (2017) menjelaskan praktik budaya Sunda dalam aktivitas ibu Postpartum di Wilayah Kerja Puskesmas Griya Antapani Bandung ibu postpartum tidak menyimpan gunting dibawah bantal sebanyak 10 orang (40\%). Meskipun pada budaya Sunda tersebut diharuskan untuk menyimpan benda tajam, gunting yang diletakkan didekat ibu untuk menangkal datangnya makhluk halus. Kesimpulan dari penelitian diatas adalah ibu postpartum sudah memiliki sikap yang negatif yaitu sudah meninggalkan budayanya tidak menyimpan benda tajam.

Pada penelitian ini didapatkan gambaran bahwa ibu budaya Melayu tidak mempercayai larangan orang tua $(95,3 \%)$. 
Mirawati $^{1}$, Dian Roza Adila ${ }^{2}$, Sekani Niriyah ${ }^{3}$, Gambaran Sikap Ibu Postpartum pada Kepercayaan Budaya Melayu

Hal ini disebabkan oleh perkembangan globalisasi yang semakin pesat yang diiringi dengan modernisasi. Modernisasi merupakan suatu proses perubahan ketika masyarakat yang sedang memperbaharui dirinya berusaha mendapatkan ciri-ciri atau karakteristik yang dimiliki masyarakat modern (Martono, (2012) dalam Nasution 2017)). Menurut Comte manusia sangat mengedepankan akal sehat pada masa era globalisasi. Pikiran manusia menyingkirkan hal-hal yang dianggapnya mitos ataupun kepercayaan bersifat abstrak, tahayul dan mistis ataupun yang bersifat susah untuk dipikirkan melalui akal sehat, oleh sebab itu masyarakat modern lebih mempercayai hal-hal yang sifatnya nyata dan dapat diterima oleh panca indra mereka (Harara, (2016) dalam Nasution 2017)). Iqbal (2012) mengatakan kebudayaan atau kultur dapat membentuk kebiasaan dan respons terhadap kesehatan dan penyakit dalam masyarakat tanpa memandang tingkatannya. Orang Melayu mempunyai animisme yaitu suatu kepercayaan yang masih menerapkan kehidupan yang sederhana dikalangan masyarakat seperti kepercayaan masyarakat terhadap pantang larang yang umum dalam kehidupan seharihari (Hamid, 1988).

\section{SIMPULAN}

Hasil penelitian menunjukkan mayoritas ibu postpartum pada suku Melayu berusia 20-40 tahun pendidikan SMA. Sementara itu sikap ibu terhadap pantangan sudah sesuai dengan kesehatan, karena sudah meninggalkan pantang seperti tidak memakai stagen, tidak mendekatkan benda tajam gunting dan peniti serta tidak percaya larangan yang dikatakan orang tuanya selama masa nifas.

\section{SARAN}

a. Bagi Ilmu Keperawatan

Bagi pendidikan keperawatan sebagai sumber informasi yang berguna untuk mengembangkan ilmu pengetahuan tentang perawatan ibu postpartum dalam budaya Melayu mana yang boleh dilakukan dan mana tidak boleh dilakukan.

b. Bagi Tenaga Kesehatan

Tetap berperan aktif dalam memberikan motivasi dan promosi kesehatan antara pandangan budaya dari segi kesehatan.

c. Bagi Responden

Diharapkan bagi ibu postpartum dalam melakukan perawatan selama masa nifas agar tetap memperhatikan fungsi kesehatan.

d. Bagi Peneliti Selanjutnya

Hasil penelitian selanjutnya diharapakan dapat dijadikan bahan masukkan mengenai sikap ibu postpartum pada kepercayaan budaya melayu. 
Diharapkan peneliti selanjutnya dengan metode kualitatif wawancara mendalam, sehingga didapatkan hasil yang lebih memuaskan.

\section{DAFTAR PUSTAKA}

Arifin, B. S. (2012). Dukungan sosial terhadap penggunaan jamu tradisional dalam perawatan ibu post partum di wilayah kerja Puskesmas Sidoharjo Sragen.

Azwar, S. (2012). Sikap manusia teori dan pengukurannya: Pustaka Pelajar

BPOM RI. (2011) Mari minum obat bahan alam dan jamu dengan baik dan benar. BPOM 12, 1-12.

Darma, K.K. (2011). Metodologi penelitian keperawatan: panduan melaksanakan dan menerapkan hasil penelitian. Jakarta Timur: CV. Trans Info Media

Dewi \& Sunarsih. (2011). Buku ajar maternitas asuhan keperawatan edisi 4. Jakarta : EGC

Donsu, J. D. T. (2016). Metodologi penelitian keperawatan. Yogyakarta: Pustaka Baru Press

Ermiati., Amrullah, J. F., \& Santoso, A. A. (2017). Praktik budaya Sunda pada ibu postpartum di wilayah kerja Puskesmas Griya Antapani.

Fadhillah, I. (2018). Perilaku ibu nifas tentang pantang makan di Desa Ngebrak kecamatan Gampengrejo kabupaten Kediri. Jurnal Keperawatan, 9 (2), 100-108.

Hamid, I. (1988). Masyarakat dan budaya melayu: Kuala Lumpur.

Kartikowati, S., \& Hidir, A. (2015). Sistem kepercayaan di kalangan ibu hamil dalam masyarakat melayu. Jurnal Parallela, 1(2), 159-167.

Kartikowati, R. S. (2017). Pola edukasi dalam sistem kepercayaan di kalangan wanita hamil masyarakat Melayu Kuantan Singingi Riau. Marwah: Jurnal Perempuan, Agama dan Jender, 14 (2), 129-144.

Lowdermilk, Perry, \& Cashion. (2013). Keperawatan maternitas ( 8 th Ed): Indonesia.

Manga \& Maryni. (2012). Ilmu sosial budaya dasar kebidanan. EGC

Maryunani, A. (2009). Asuhan pada ibu dalam masa nifas (post partum). CV. Trans Info Media: Jakarta

Maritalia, D. (2012). Asuhan kebidanan nifas dan menyusui. Pustaka Pelajar: Yogyakarta

Moehji, S. (2002). Ilmu Gizi 1: Pengetahuan dasar ilmu gizi. Jakarta: Papas Sinar Sinanti

Munawaroh. (2013). Panduan memahami metodologi penelitian. Malang: Intimedia

Nasution, R. D. (2017). Pengaruh perkembangan teknologi informasi komunikasi terhadap eksistensi budaya lokal. Jurnal penelitian komunikasi dan opini publik, 21 (1), 30-42.

Potter, P. A., Perry, A.G. (2005). Buku ajar fundamental keperawatan: konsep, proses, dan praktik. Ed 4. Vol 1. Jakarta: EGC

Rahayu, I. S., Mudatsir, M., \& Hasballah, K. (2017). Faktor budaya dalam perawatan ibu nifas. Jurnal Ilmu Keperawatan, 5 (1), 36-49.

Rahayu, D. T. (2018). Pendidikan komunitas tentang pemakaian bengkung pada ibu nifas di Desa Keling kecamatan Kepung kabupaten Kediri. at-tamkin: Jurnal pengabdian kepada masyarakat, 1(1), 35-44.

Rahman, L.M., Marni, T., \& Zulkarnain. (2003). Alam melayu sejumlah gagasan menjemput keagungan. Unri Press: Publisher. 
Mirawati', Dian Roza Adila ${ }^{2}$, Sekani Niriyah ${ }^{3}$, Gambaran Sikap Ibu Postpartum pada Kepercayaan Budaya Melayu

Rini, Y. (2017). Perilaku keluarga suku melayu dalam merawat ibu nifas di Puskesmas Desa Lama kecamatan Sei Lepan kabupaten Langkat.

Riyanto, A. (2011). Aplikasi metodologi penelitian kesehatan. Yogyakarta: Yuha Medika

Saam, Z \& Wahyuni, S. (2014). Psikologi keperawatan. Jakarta: Rajawali Pers

Sembiring, D. E. (2011). Pengalaman suku melayu dalam perawatan masa nifas di Desa Perhiasan kecamatan Selesai kabupaten Langkat. Pengalaman suku melayu dalam perawatan masa nifas di Desa Perhiasan kecamatan Selesai kabupaten Langkat.

Saminem. (2009). Buku ajaran keperawatan maternitas. Jakarta: EGC

Setiadi., \& Elly, M. (2008). Ilmu Sosial dan Budaya dasar. Prenada Media Group: Jakarta.

Surjarweni, W. V. (2014). Metodologi penelitian lengkap, praktis dan mudah dipaham. Yogyakarta: Pustaka Baru Press

Suwardi. (2008). Dari melayu ke Indonesia. Yogyakarta: Pustaka Pelajar Swasono, M.F. (2004). Kehamilan, kelahiran, perawatan ibu dan bayi dalam konteks budaya. Jakarta: UI Press

Wawan, A \& Dewi, M. (2010). Teori dan pengukuran pengetahuan, sikap dan perilaku manusia. Yogyakarta: Nuha Medika

Widagdho, J., dkk. (2012). Ilmu budaya dasar (12 th Ed 1). Jakarta: Bumi Aksara.

World Health Organization. (2010). WHO technical consultation on post partum and postnatal care.

Wulansari, M. A., \& Yudha, E. A. L. (2017). Gambaran pengetahuan dan sikap ibu tentang pantang makanan selama masa nifas di BPM Sri Lumintu. URECOL, 151-156.

Yugistyawati, A. (2013). Pengaruh pendidikan kesehatan masa nifas terhadap kemampuan perawatan mandiri ibu nifas post sectio caesarea (SC). Jurnal Ners dan Kebidanan Indonesia, 1 (3), 96-100.

Yusuf, A. M. (2014). Meteodologi penelitian: kuantitatif, kualitatif, dan penelitian gabungan. Jakarta:

Kencana 